\title{
Targeting androgen receptor as a new potential therapeutic approach to battle tobacco carcinogens-induced non-small cell lung cancer
}

\author{
Shauh-Der Yeh ${ }^{1,2^{*}}$, Pan-Chyr Yang ${ }^{2}$, Hsuan-Hsuan Lu' ${ }^{1}$ Chawnshang Chang ${ }^{1,3^{*}}$, Cheng-Wen Wu ${ }^{2}$ \\ From 2012 Sino-American Symposium on Clinical and Translational Medicine (SAS-CTM) \\ Shanghai, China. 27-29 June 2012
}

\section{Background}

Lung cancer is the leading cause of cancer death worldwide. Non-small cell lung cancer (NSCLC) accounts for the majority of lung cancer. The incidence and prognosis in NSCLC demonstrates gender difference [1,2]; therefore, sex steroids and/or their receptors may play important roles during lung tumorigenesis and cancer progression. In our previous investigation, cell proliferation, migration, invasion, and tumor formation were inhibited by shRNA interference of androgen receptor (AR) in non-small cell lung cancer (NSCLC) cells lines. The expressions of cyclin D1 also decreased to less than $50 \%$ after AR knockdown. However, the roles of androgen receptor in treatment of NSCLC are still controversial.

\section{Materials and methods}

To validate therapeutic effects of targeting androgen receptor on NSCLC, initially we administered 8 doses of tobacco carcinogens, 4-(methylnitrosamino)-1-(3-pyridyl)-1-butanone (NNK) and benzo[a]pyrene (BaP), to induce lung tumor growth in female A/JB6.129-Ar ${ }^{l o x} \mathrm{Tg}$ (Mx1-cre)1Cgn mice when they were 5 weeks old. In the next step, targeted $A r$ gene disruption was induced with 6 doses of polyinosinic: polycytidylic acid (polyI:C) intraperitoneal injection in Mx1-cre+ mice when they were 26 weeks old. We also performed 6 doses of normal saline injection to $\mathrm{NNK}+\mathrm{BaP}$-treated female A/JB6.129-Ar ${ }^{l o x}$ $\mathrm{Tg}(\mathrm{Mx} 1$-cre $) 1 \mathrm{Cgn}$ mice in the same time point for the control group. Finally, all mice were sacrificed in 31 weeks old and total lung nodules and tumor larger

\footnotetext{
* Correspondence: d8602003@gmail.com

'Department of Urology and Center of Excellence for Cancer Research,

Taipei Medical University and Hospital, Taipei, 110, Taiwan

Full list of author information is available at the end of the article
}

than $1 \mathrm{~mm}$ in diameter were calculated under dissection microscope.

\section{Results}

In immunohistochemical studies, AR expression in lung was deficient in Mx1-cre+ mice after polyI:C treatment. Pulmonary expression of cyclin D1 was also suppressed in polyI:C treated Mx1-cre+ mice. The number of total nodules in bilateral lungs from polyI:C treated $\mathrm{Mx1}$-cre+ mice $(n=8)$ was $7.375 \pm 5.476$ (mean \pm S.E.). In comparison, the total number of lung nodules from normal saline treated Mx1-cre+ mice ( $\mathrm{n}=8)$ was $14.375 \pm 7.269(\mathrm{p}=$ $0.0456,95 \%$ CIs on the mean $=9.235$ to 19.515$)$. The number of large nodules ( $>1 \mathrm{~mm}$ in diameter) in bilateral lungs was $1.375 \pm 1.188$ in polyI:C treated Mx1-cre+ mice and $6.25 \pm 4.464$ in normal saline treated Mx1-cre+ control mice $(\mathrm{p}=0.00492,95 \%$ CIs on the mean $=3.093$ to 9.407). Deficient AR expression through inducible disruption of $A r$ gene could reduce lung tumor multiplicity and further inhibit tumor progression (decrease tumor volume) in tobacco carcinogens-induced lung tumorigenesis model.

\section{Conclusions}

Our data indicate that androgen receptor warrants consideration as a novel therapeutic target for NSCLC in a clinical lung cancer treatment trial.

\section{Author details \\ ${ }^{1}$ Department of Urology and Center of Excellence for Cancer Research, Taipei Medical University and Hospital, Taipei, 110, Taiwan. ${ }^{2}$ Institute of Biomedical Sciences, Academia Sinica, Taipei, 115, Taiwan. ${ }^{3}$ Department of Pathology, University of Rochester, Rochester, NY 14642, USA.}

Published: 17 October 2012 


\section{References}

1. Sekine I, Sumi M, Ito $Y$, et al: Gender difference in treatment outcomes in patients with stage III non-small cell lung cancer receiving concurrent chemoradiotherapy. Jpn J Clin Oncol 2009, 39:707-712.

2. Sakurai $H$, Asamura $H$, Goya $T$, et al: Survival differences by gender for resected non-small cell lung cancer: a retrospective analysis of 12,509 cases in a Japanese Lung Cancer Registry study. J Thorac Oncol 2010, 5:1594-1601.

doi:10.1186/1479-5876-10-S2-A8

Cite this article as: Yeh et al:: Targeting androgen receptor as a new potential therapeutic approach to battle tobacco carcinogens-induced non-small cell lung cancer. Journal of Translational Medicine 2012 10(Suppl 2):A8.

\section{Submit your next manuscript to BioMed Central} and take full advantage of:

- Convenient online submission

- Thorough peer review

- No space constraints or color figure charges

- Immediate publication on acceptance

- Inclusion in PubMed, CAS, Scopus and Google Scholar

- Research which is freely available for redistribution

Submit your manuscript at www.biomedcentral.com/submit 